\title{
Možnosti kombinovaných způsobů úpravy vybraných druhů odpadů za pomoci experimentálního zařízení pro fyzikální zpracování odpadů za účelem jejich dalšího využití
}

\section{TOMÁŠ SEZIMA, EUGEN SIKORA, RADMILA KUČEROVÁ}

Klíčová slova: životní prostředí - odpad - zpracování odpadů - fyzikální zpracování odpadů snižování nebezpečných vlastností - biotechnologie - biodegradace

\section{SOUHRN}

Příspěvek prezentuje možnosti originálního zařízení pro fyzikální zpracování odpadů, chráněného evropským patentem a zamýšlí se nad perspektivami jeho dalšího rozvoje. Toto zařízení využívá jednotlivá nebo kombinovaná působení ultrazvuku, fokusovaného mikrovInného pole, jiskrového výboje, elektrostatického pole a UV zárení za účelem snižování nebezpečných vlastností odpadů, dané prítomností nebezpečných látek pro další využití (materiálové nebo energetické), a to samostatně nebo $v$ kombinaci s dalšími technologickými postupy, např. s biotechnologiemi.

V současnosti jsou známy miliony rưzných chemických látek a každý den jsou syntetizovány další a další. Chemizace nejrůznějších odvětví průmyslu je př́činou nárůstu masové kontaminace prostředí cizorodými látkami. Zpracování odpadů je $v$ dnešní době většinou náročný technologický proces, který je směřován k materiálovému a energetickému využití odpadů - vede k získání druhotných surovin. Tyto suroviny jsou po zpracování využívány znovu např. ve výrobě, a proto jsou dnes mnohdy na světových trzích již velmi ceněnou obchodní komoditou.

V souladu se strategií nakládání s odpady, její hierarchizací, se v současnosti klade důraz na materiálové či energetické znovuvyužití surovin.

Už kolem roku 1960 byly publikovány první informace ohledně pưsobení různých silových polí, zejména elektromagnetických, na člověka a životní prostředí.

$\checkmark$ současné době se této problematice samostatně, a nebo $v$ kombinaci s biotechnologiemi, věnuje řada pracovišt, významnější publikace jsou uvedeny $v$ prehehledu literatury [1-6].

Jednou z možností zpracování odpadů jsou fyzikální způsoby úpravy. V letech 2007-2011 bylo výzkumnými pracovníky Výzkumného ústavu vodohospodářského T. G. Masaryka, v. v. i., Praha v rámci projektu MŽP VaV SP/2f2/98/07 „Výzkum v oblasti odpadů jako náhrady primárních surovinových zdrojü“ započat vývoj zařízení na zpracování odpadů fyzikálními postupy. Koncept zařízení byl zapsán jako užitný vzor - Číslo zápisu: Int. 21084, Úřad prưmyslového vlastnictví dne 2. 7. 2010 [7]. Zařízení a zpưsobu fyzikálního zpracování odpadu byl udělen dne 22. 8. 2014 evropský patent EP 2388068 [8].
Zařízení a způsob fyzikálního zpracování odpadu - oblast techniky/technologie

Zařízení pro fyzikální úpravu materiálů (zejména pevných matric odpadů) koncepčně spočivá $v$ jednotlivém nebo ve vybraném kombinovaném pưsobení vybraných silových polí (mikrovlnné pole, ultrazvuk, UV záření, jiskrový výboj, elektrostatické pole - studená plazma a popř. i dalších).

\section{Dosavadní stav techniky}

V současné době jsou dostupná zařízení, nebo jsou známé popisy agregátů pro generování jednotlivých silových polí. Zajištění kombinovaného působení více silových polí na sledovanou matrici je obtížné, nebot komerčně dostupná zařízení jsou většinou konstruovaná pro presně vymezený účel, což brání jejich propojování do sestavy. Sestavení a sladění kombinovaného zařízení pro fyzikální úpravu materiálů z komerčně dostupných generátorů - zdrojů silových pưsobení nebyla možná. V sestavě bylo možné použití jen zdroje UV zárení, který byl běžně komerčně dostupný a byl takto převzat a po drobné úpravě použit. Další jednotlivé generátory silových polí musely být sestavovány individuálně s ohledem pro zamýšlené vícealternativní využití - jednotlivé i kombinované, a to z vhodných elektronických součástek, s ohledem na výkon, výdrž - celkovou dobu použití a cenu apod. Konečným cílem zařízení je především zkoumání kombinací působení fyzikálních jevů silových polí nejlépe v superpozici (synergické působení).

\section{Podstata technického řešení}

Navržené zařízení pro fyzikální úpravu odpadů je sestaveno z jednotlivých generátorů fyzikálních silových polí umístěných v průhledném boxu s vetkanou, uzemněnou Faradayovou klecí s otvíracím vstupním - manipulačním otvorem. Na dně boxu je volně položen podstavec z elektricky nevodivého materiálu, na kterém leží plastová nádoba - vana, pro vložení sledované matrice pro expozici vzorků. Dno nádoby tvoři silná vrstva plastu s velmi vysokým ohmickým odporem. Na dnu nádoby při expozici elektrostatickým polem je 
volně položena elektricky dobře vodivá kovová mřížka. Nad nádobou je bud' vnořená do vzorku, nebo volně zavěšená nad vzorkem druhá kovová mřížka. Obě mř́žky jsou napojeny elektrickým vodičem na generátor elektrostatického pole - studené plazmy. Unášecí most s posuvem nese generátor UV záření a generátor jiskrového výboje. Posun mostu je zrealizován elektrickým pohonem s možností změny rychlosti pohybu ve dvou stupních a s pohybem ve dvou směrech (tam a zpět). Při dojezdu na konec vymezené dráhy pojezdu dochází k automatickému překlopení směru pohybu pomocí koncových dojezdových přepínačů. Délka pojezdu je mechanicky nastavitelná. Expozice elektrickým jiskrovým výbojem je realizována jiskřištěm, které je umístěno na unášecím mostě. Generátory silových polí mohou pracovat současně, v různých kombinacích následností nebo samostatně. Aktuálně nelze zrealizovat společné působení silového elektrostatického pole - studené plazmy a elektrického jiskrového výboje (nebezpečí poškození elektroniky jiskrovým výbojem). Schéma konceptu zařizení je znázorněno na obr. 1.

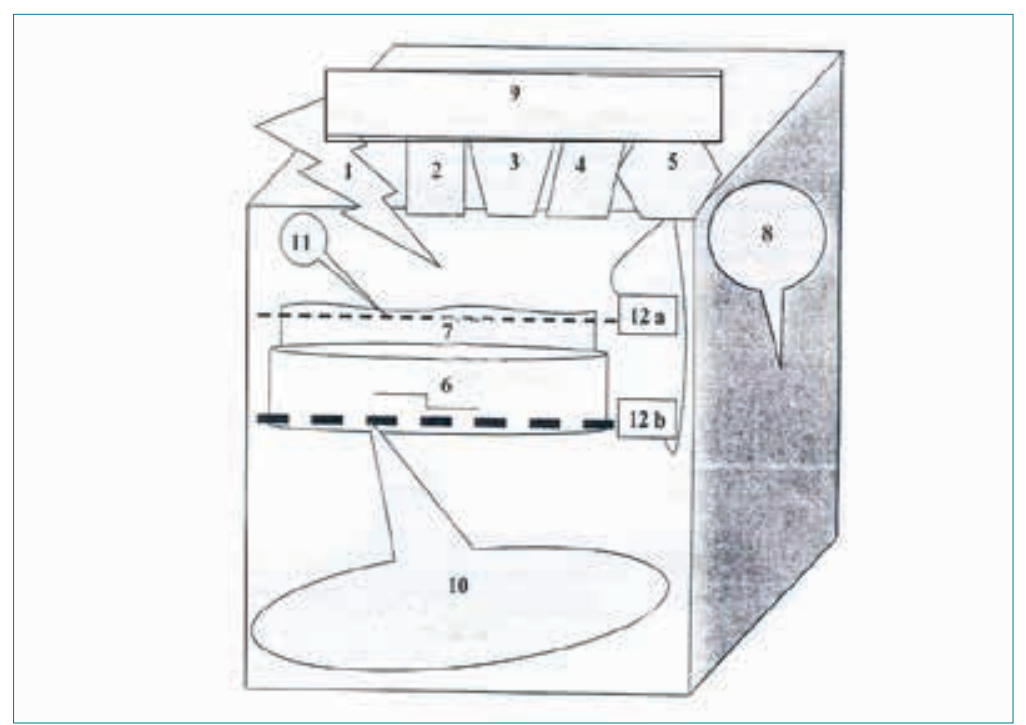

Obr. 1. Schéma zařízení pro fyzikální předúpravu odpadu

Vysvětlivky: 1, 2, 3, 4, 5 - generátory silových polí (jiskrový výboj - vysokotepelná plazma, mikrovlnné pole, ultrazvuk, UV záření, elektrostatické pole - studená plazma), 6 - plastová vana (nádoba na vzorek), 7 - zkoumaný vzorek, 8 - Faradayova klec, 9 - posuvný most, 10, 11 - vodivá kovová mř́žka, 12 a, b - přívodní kabely VN Fig. 1. Diagram of the device for physical waste pre-treatment Legend: 1, 2, 3, 4, 5 - force field generators (spark discharge - high-temperature plasma, microwave field, ultrasound, UV radiation, electrostatic field - non-thermal plasma), 6 - plastic vessel (container for a sample), 7 - sample investigated, 8 - Faraday cage, 9 - carrier bridge, 10, 11 - conductive metal mesh, 12 a, b - HV supply cables

\section{Předmět použití}

Zařízení a způsob fyzikálního zpracování odpadu je možno využít samostatně nebo ve vhodné kombinaci s jinými technologiemi a postupy. Použití zařízení je cíleno na snižování obsahu hưre rozložitelných, vysoce škodlivých polutantů, např. na polycyklické aromatické uhlovodíky (PAHs), perzistentní organické látky (POPs), např. polychlorované bifenyly (PCB), xenobiotika apod.

Zařízení bylo laboratorně využíváno pro snižování koncentrace problematických polutantů ve vybraných typech odpadů za účelem jejich znovuvyužití materiálového (hnojivé nebo rekultivační směsi) a nebo energetického (tvorby tuhých alternativních vícesložkových směsných paliv). Jednalo se např. o čistírenské kaly z komunálních a průmyslových čistíren odpadních vod, papírenské kaly, plasty, odpady z úpravy uhlí, odpady z potravinářského průmyslu a další.
Při experimentálních pokusech s fokusovaným mikrovlnným polem (MW) byl zjištěn maximální úbytek sumy 15 PAHs 43,92 \%, s ultrazvukovým působením nebylo zjištěno prokazatelně snižování obsahu PAHs, s ultrafialovým zářením (UV) byl zjištěn maximální úbytek sumy 15 PAHs 9,92 \%, s jiskrovým výbojem byl maximální úbytek sumy 15 PAHs 12,39\%, s působením elektrostatického pole byl maximální úbytek sumy 15 PAHs 45,07 \%. Zajímavých úrovní degradace bylo také dosahováno např. i u AOX, specificky perzistujících PCB, a to při použití kombinovaných fyzikálních technik úpravy odpadů. Výše degradace je mnohdy závislá na dostupných výkonech zařízení. Výkon generátorů jednotlivých silových polí zařizení byl limitován finančními prostředky, které byly k dispozici pro výzkum této oblasti v době řešení projektu. U námi navrženého zařízení byla projektem ověřena správnost koncepce a jeho funkčnost.

Působení na odpadní materiály za pomoci výše popsaného zařízení Ize vhodně kombinovat $s$ dalšími chemickými nebo biochemickými technologiemi a postupy. Vhodné se jeví biotechnologie (biodegradace), kdy fyzikální postupy slouží k iniciaci - otevření a zpřístupnění matric pro další působení.

Biodegradace nebezpečných škodlivých látek $v$ životním prostředí představují významné perspektivní metody, kdy jsou složité a ekologicky závadné polutanty působením mikroorganismů rozkládány na látky jednodušší (nezávadné). Principem biodegradačních technologií je optimalizace živinových poměrů (pro podporu růstu vybraných mikroorganismů schopných degradovat cílové kontaminanty) a aplikace vhodně vybraných izolovaných kmenů mikroorganismů s příslušnou degradační schopností [9].

Biologické metody dekontaminace využívají vlastní nebo inokulované mikroorganismy (houby, bakterie a ostatní mikroorganismy) k rozkladu (metabolizaci) organických polutantů obsažených v půdách nebo podzemních vodách.

Při aplikaci biodegradačních metod je třeba vycházet z faktu, že tento proces je velice komplexní. Úspěšnost či neúspěšnost závisí především na těchto faktorech [10-12]: chemických (druh kontaminantu, pH prostředí, koncentrace makro a mikrobiogenních prvků, obsah vody, chemické složení kontaminovaného materiálu, chemické složení a koncentrace vhodných nutričních roztoků apod.), mikrobiologických (degradační aktivita mikroorganismů) a fyzikálních (teplota, rozpustnost ve vodě, sorpce na pevné částice).

Vzhledem k tomu, že každý z výše uvedených faktorů má vliv na průběh biodegradace, je zřejmé, že při návrhu technologických postupů a jejich aplikací je třeba tyto faktory vzít $v$ úvahu a v prípadě potřeby je upravit tak, aby biodegradační proces byl co nejméně limitován.

Rychlost samovolného biodegradačního procesu na sanovaných lokalitách je bez vnějších zásahů velmi nízká především z následujících důvodů: nízké pozadí původní půdní mikroflóry, neprítomnost specifické mikroflóry, velmi nízká rozpustnost př́tomných polutantů, nehomogenní rozšíření polutantů, nedostatek kyslíku (při aerobní biodegradaci), nedostatek doplňkových živin.

Vhodným sanačním postupem je možné zvýšit rychlost biologických procesů o několik rádů. Aplikované bakteriální kmeny musí vždy splňovat následující podmínky:

— jedná se o běžné půdní bakteriální kmeny (v žádném prípadě nesmí jít o kmeny geneticky manipulované),

- bakteriální kmeny jsou netoxické a nepatogenní a jejich uživání je schváleno Státním zdravotním ústavem a hlavním hygienikem ČR,

- přináší do sanovaného ekosystému enzymatický systém, napomáhající rozkladu polutantů na konečné oxidační produkty; pokud výsledným produktem určitého bakteriálního kmenu není oxid uhličitý, voda a biomasa, musí na jeho činnost navazovat jiný bakteriální kmen.

Rozklad organických látek pomocí mikroorganismů je součástí přirozeného způsobu koloběhu uhlíku v prírodě. Proces biodegradace je založen na schopnosti mikroflóry využívat prítomné škodliviny jako zdroj uhlíku a energie ke svému růstu. 
Bylo identifikováno více než 200 druhů mikroorganismů schopných degradovat uhlovodíky, přičemž pořadí jejich důležitosti je následující: heterotrofní bakterie, houby, aerobní bakterie, aktinomycety, fototrofy a oligotrofní bakterie. Nejčastěji používané bakterie se řadí k rodưm Pseudomonas, Arthrobacter, Acinetobacter, Flavobacterium, Alcaligenes, Micrococcus a Corynebacterium [13]. Intenzivní výzkum v této oblasti potvrzuje, že uplatnění vedle bakterií najdou i jiné mikroorganismy včetně hub a řas. Pro lepší orientaci slouží následující přehled [14].

\section{Přehled aerobních mikroorganismů degradujících uhlovodíky}

Bakterie: Pseudomonas, Acinetobacter, Alcaligenes, Torulopsis, Bacillus, Arthrobacter, Chlorella, Brevibacterium, Corynebacterium, Mycobacterium, Aeromonas, Moraxelia, Beijerinckia, Flavobacterium, Achromobacter, Nocardia, Micrococcus, Rhodococcus, Sarcina, Acetobacter.

Houby: Phyktochytrum, Phizophlyctis, Mucor, Phytophthora, Thraustochytrum, Aspergillus, Cunninghariela, Syncephalastrum, Girbeltella, Absidia, Zygorrhynchus, Penicillium, Choanephora, Phycomyces, Circinella, Thamnidium, Rhizopus, Basidiobolus, Conidiobolus, Smittium, Saproiegnia, Saccharomyces, Emericellopsis, Neuropora, Sordana, Claviceps, Candida, Debaryomyces, Streptomyces.

Řasy: Oscillatoria, Microcoleus, Anabaena, Agmenellum, Nortoc, Coccochloris, Aphanocapsa, Porphyridium, Petalonia, Ulva, Cylindrotheca, Amphora, Nitzschia, Navidula, Chlorella, Dunaliella, Chlamydomonas.

Vzhledem ke komplexnosti biodegradačních procesů mají tyto mikroorganismy nejrůznější metabolické vybavení. Skladba mikrobní populace v otevřeném biologickém systému je do značné míry dána teplotou prostředí (nejčastěji jsou zde zastoupeny mesofilní druhy s teplotním optimem v rozmezí $\left.14-40^{\circ} \mathrm{C}\right)$.

Vzorky čistírenských kalů byly podrobeny laboratorním biodegradačním experimentům $\vee$ prostorách Katedry environmentálního inženýrství VŠB - TUO. Pro biodegradaci byla použita směs bakterií Pseudomonas putida a Rhodococcus sp., které byly získány z České sbírky mikroorganismů působící při Prírodovědecké fakultě Masarykovy univerzity v Brně. Česká sbírka mikroorganismů disponuje značným spektrem mikroorganismů, k nimž je vytvořena podpưrná databáze s jejich degradačními schopnostmi a specifickými vlastnostmi a podmínkami kultivace.

Pro správnou kultivaci byly živiny zajištěny nutričními roztoky - kultivačními médii, a to M1 pro Pseudomonas putida a M96 pro Rhodococcus sp.

Část vzorků byla biodegradována bez předúpravy a u dalších byly vzorky před vlastní biodegradací podrobeny fyzikální předúpravě na zařízení pro fyzikální předúpravu v laboratořích Vúv TGM, v. v. i. Pro předúpravu byly zkoušeny různé postupy - fokusované mikrovInné pole, ultrazvuková vana, jiskrový výboj, elektrostatické pole a UV zárení.

Vlastní biodegradace probíhaly po dobu maximálně 4 týdnů. Poté byly vzorky zfiltrovány a po citlivém usušení provedeny speciální chemické analýzy. Vzhledem k charakteristice daného vzorku kalu byly stanovovány zejména polycyklické aromatické uhlovodíky (PAHs) a polychlorované bifenyly (PCBs).

Nejlepšího výsledku kombinovaných technik se dosáhlo u nevápněného čistírenského kalu po biodegradaci s bakteriální kulturou v kombinaci s fyzikální předúpravou elektrostatickým polem, kdy došlo k odstranění 54,0 \% původního znečištění sumy 15 PAHs.

Lze konstatovat, že kombinace působení fyzikální předúpravy a biodegradačních postupů se jeví perspektivní z hlediska účinnosti a spektra působení.

Vize, projektování a vlastní realizace výstavby zařízení byla limitována finančními prostředky. V současné době se řeší optimalizace a dostavba, a to zejména části zařízení pro fyzikální zpracování odpadů elektrostatickým polem, dále koncepce SW pro měření a regulaci. V této fázi výzkumu a vývoje zařízení se bude jednat o postupnou optimalizaci silové VN části a základní měření s regulací, měření základních jakostních parametrů procesu, měření a regulaci doplňkových parametrů procesu, přenos dat a vizualizace. Koncept zařizení je zachován, nebude měněn. Pouze bude řešena optimalizace zařízení ve všech směrech (výkonové, měření a regulace, archivace a přenos dat, vizualizace).

Při experimentálních pracích jsou aktuálně využívány vybrané generátory silových polí, a to UV záření, jiskrového výboje, elektrostatické pole - studené plazmy. Proces fyzikálního zpracování odpadu je zobrazen na obr. 2.
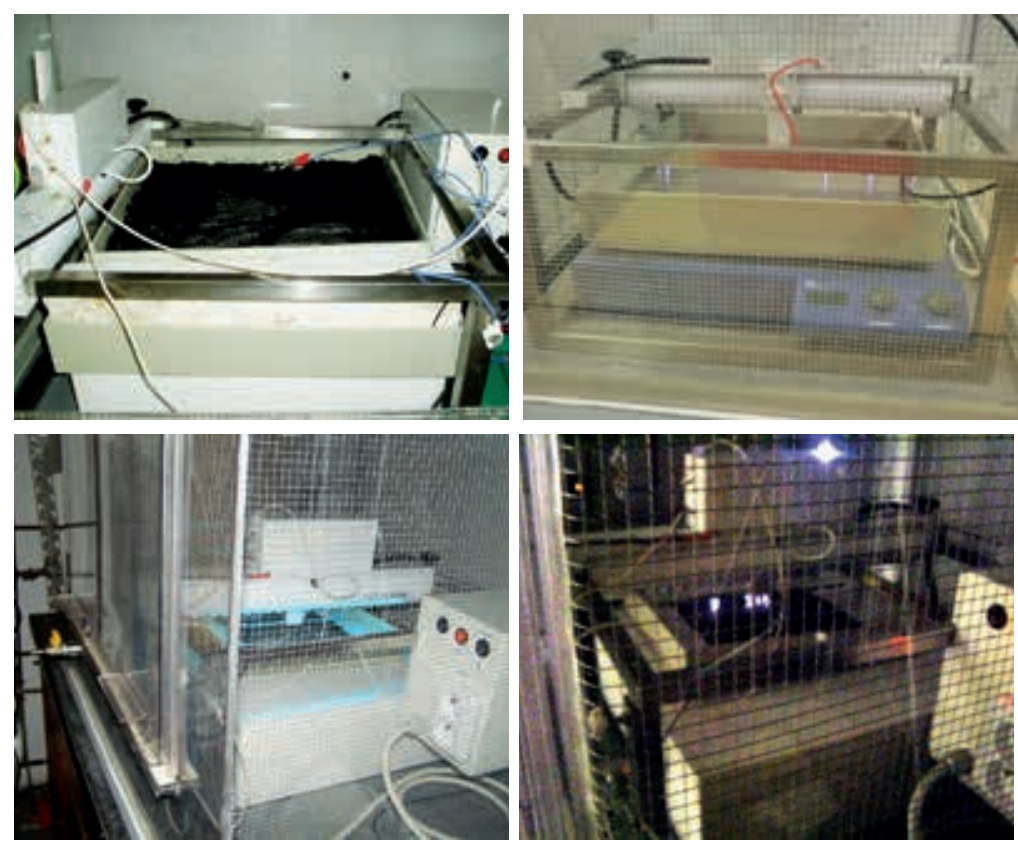

Obr. 2. Fotodokumentace zařízení pro fyzikální úpravu odpadů - EP 2388068 (elekt rostatické pole, jiskrový výboj, UV záření)

Fig. 2. Photographic evidence of the device for physical waste treatment - EP 2388068 (electrostatic field, spark discharge, UV radiation)

Pokud je zamýšleným finálním produktem využití upravených odpadních látek alternativní palivo, pak je třeba z vytipovaných, upravených odpadů vytvořit recepturu, zkušební vzorky alternativních paliv laboratorně otestovat, udělat výběr receptur a postupů pro tvorbu alternativních paliv.

Podle nejvhodnější a nejperspektivnější receptury připravit vícesložkové směsné alternativní palivo na bázi odpadů. Potřebné množství paliva pro ověřovací spalné zkoušky zhomogenizovat, podle potřeby upravit na granule nebo pelety. Minimální množství vyrobeného paliva pro spalné zkoušky je dáno jeho sypnou hmotností. Pro certifikaci paliva je nutno spalné zkoušky vždy provádět $\checkmark$ akreditované laboratoři.

Příprava a testování tuhých alternativních vícesložkových směsných paliv jsou zobrazeny na obr.3.

Celý proces znovuvyužití vybraných druhů odpadů (materiálové či energetické) byl pod důkladnou chemickou analytickou kontrolou, toxikologickým a genotoxikologickým sledováním. Projekt vygeneroval dvě speciální certifikované metodiky, a to Metodiku pro skupinové stanovení fenolů v kalech a Metodiku stanovení genotoxických účinkủ látek obsažených v čistírenských kalech pomocí Amesova fluktuačního testu.

Probíhající optimalizace - dostavba zařízení spočívá aktuálně v navýšení zdroje VN na 20 kV, zpracování základního měření a regulace. Proces fyzikálního zpracování odpadu je zobrazen na obr. 4-6. 


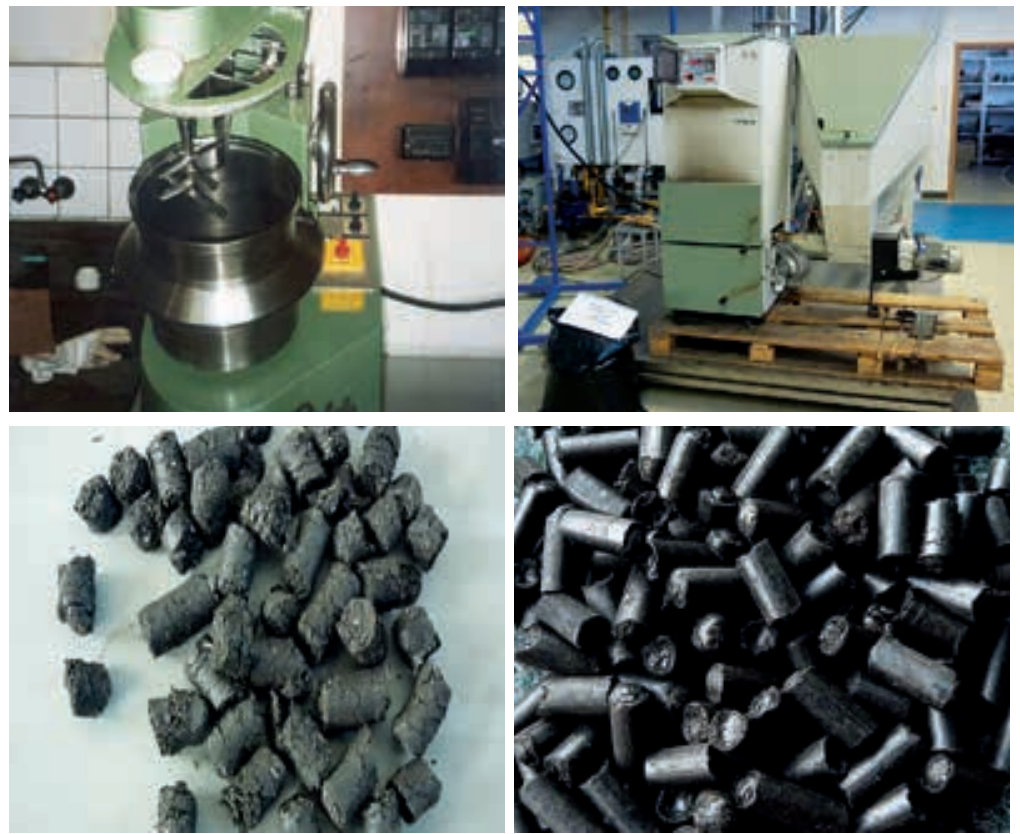

Obr. 3. Fotodokumentace - alternativní vícesložkové palivo na bázi odpadů, upravených na zařizení pro fyzikální úpravu odpadů podle EP 2388068 „Device for physical waste treatment" - homogenizace složek před granulací ve spolupráci s VÚHU a. s., Most, spalné zkoušky na certifikovaném testovacím zařízení VŠB - TUO v Ostravě, ukázky finálního granulovaného vícesložkového tuhého alternativního paliva

Fig. 3. Photographic evidence - alternative multicomponent fuel based on fuels treated on the device for physical waste treatment as per EP 2388068 "Device for Physical Waste treatment" - homogenisation of components at the stage before granulation in cooperation with Czech Brown Coal Research Institute, Inc. (VÚHU a.s.) in Most, combustion testing on a certified testing equipment at VSB - Technical University in Ostrava, examples of final granulated multicomponent solid alternative fuel

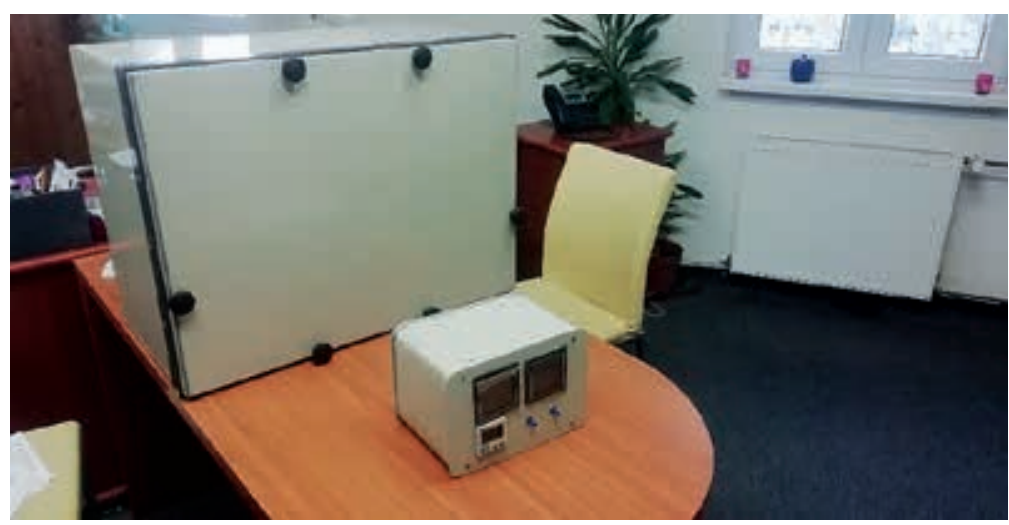

Obr. 4. Elektrický rozvaděč pro navýšený zdroj VN, řídicí jednotka pro elektrostatické pole

Fig. 4. Electrical switchboard for increased HV source, control unit for electrostatic field

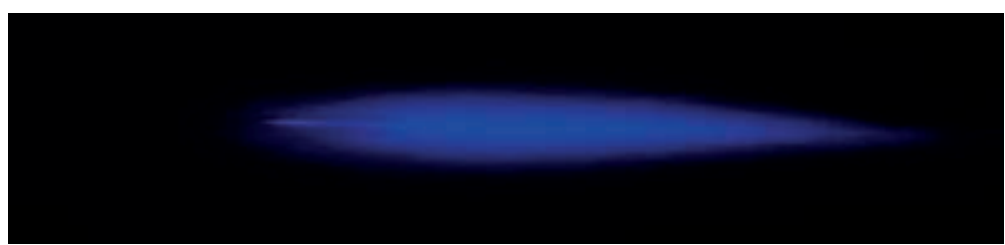

Obr. 5. Výboj na hrotu elektrody

Fig. 5. Discharge on the tip of electrode

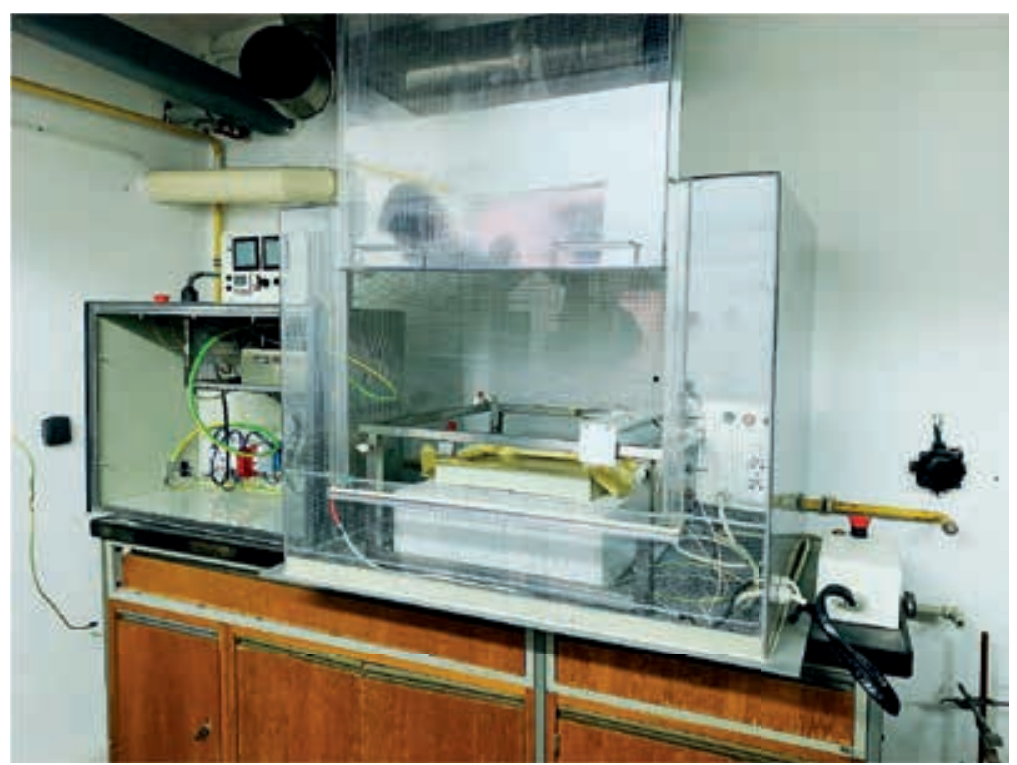

Obr. 6. Optimalizované zkušební - experimentální zařízení pro fyzikální zpracování odpadů v laboratoř

Fig. 6. Optimised testing and experimental equipment

\section{DISKUSE A ZÁVĚR}

Zpracování odpadů vede k většímu opětovnému využití, a proto jsou v dnešní době nové techniky a technologie vítány a ve správném čase i společností podporovány, a to $v$ rámci naplňování trvale udržitelného rozvoje.

Zařizení pro fyzikální úpravu materiálů (zejména pevných matric odpadů) koncepčně spočívá v jednotlivém nebo kombinovaném působení vybraných silových polí, a to bud' jako samostatná technologie anebo v kombinaci s jinými dalšími. V současné době je zařízení vystavěno jako zkušební laboratorní zařízení, po optimalizaci a dostavbě výhledově i jako zařízení prưmyslové. Zařízení může být využito také jako speciální zařízení pro testování odolnosti materiálů vůči různým kombinovaným účinkům silových polí nebo jako zařízení pro čištění nebo hygienizaci vyráběných nových sloučenin a materiálů.

$\checkmark$ současné době probíhá spolupráce $s$ dalšími výzkumnými pracovišti, zejména dislokovanými na vysokých školách, a zkušební testování odpadů v rámci uživatelské optimalizace zařízení. Dále jsou vedena jednání s výrobci zkušebních laboratorních a průmyslových technických zařizení a také s odbornými odpadářskými firmami, zabývajícími se zpracováním vybraných druhů odpadů za účelem dalšího využití či bezpečné likvidace. Trvale je budována sít profesionálních partnerů. V rámci komercionalizace patentu je pro další rozvoj, využití a uplatnění zařizení hledán významný a silný strategický partner.

\section{Poděkování}

Všem zúčastněným na tomto projektu výzkumu a vývoje využiváni odpadů jako náhrady primárních prírodnich zdrojů a Ministerstvu životního prostředí za finanční, odbornou a metodickou podporu při rešení projektu. Výzkum a vývoj byl podpořen projektem Ministerstva životního prostředi České republiky (VaV SP/2f2/98/07). 


\section{Literatura}

[1] BALAKRISHNAN, S.K. Degradation of organic pollutants in water by non-thermal plasma based advanced oxidation processes = Degradace organických znečištujicićch látek ve vodě nízkoteplotním plazmatem na bázi pokročilých oxidačnich procesü. Vodňany: Faculty of Fisheries and Protection of Waters, University of South Bohemia in Ceské Budějovice, 2017. 87 str. ISBN 978-80-7514-058-6.

[2] BARTUSEK, S., PRYSZCZ, A., and OBROUČKA, K. Energy and material recovery process combined reduction and plasma at the new facility of The Institute of Environmental Technology. Conference on Environment and Mineral Processing, 2013, 17, p. 325-329. ISBN 978-80-248-3000-1.

[3] FERIANCOVÁ, A. et al. Spracovanie PVC odpadov z káblov pomocou mikrovlnného žiarenia. Hutnické listy, 2015, roč. 68, č. 5, s. 68-71. ISSN 0018-8069. Dostupné také z: https://www.hutnickelisty. cz/download/674

[4] HÁJEK, M. MikrovInná recyklace odpadních PET lahví. Odpady, 2014, roč. 24, č. 6, s. 25-26. ISSN 1210 4922. Dostupné také z: https://odpady-online.cz/mikrovlnna-recyklace-odpadnich-pet-lahvi.

[5] LÁZÁR, M. et al. Refuse-derived fuel energy recovery by plasma technology. Sborník vědeckých pracílysokéškoly báňské - Technické univerzity Ostrava Řada stroini 2014 roč 60 č 1, s. 69-76. ISSN 12100471. Dostupné také z: http://transactions.fs.vsb.cz/2014-1/1980.pdf

[6] BANU, J.R. et al. Energetically efficient microwave disintegration of waste activated sludge for biofuel production by zeolite: Quantification of energy and biodegradability modelling. Internationa Journal of Hydrogen Energy. 2018, ISSN: 0360-3199.

[7] SEZIMA, T. a SIKORA, E. Užitný vzor - Zařízení pro fyzikální úpravu odpadů - Osvědčení o zápisu užitného vzoru, číslo zápisu: Int. 21084, Úřad průmyslového vlastnictví.ze dne 2.7.2010, v rámci projektu VaV SP/2f2/98/07 Výzkum v oblasti odpadů jako náhrady primárních surovinových zdrojů (2007-2011, MŽP/SP), dostupné z https://isdv.upv.cz/webapp/webapp.vestnik.seznam?lan=cs\&pdprr=2010 nebo https://isdv.upv.cz/doc/vestnik/2010/vestnik_UPV_201028.pdf

[8] SEZIMA, T. a SIKORA, E. Evropský patent EP 2388068 „Device for physical waste treatment", datum zápisu 22.08.2014, dostupné z https://patentimages.storage.googleapis.com/01/b0/66/ 2f4267549e5b1f/EP2388068B1.pdf

[9] PÁCA, J., SUCHÁ, V., MIKŠANOVÁ, M. a STIBOROVÁ, M. Enzymy kvasinky Candida tropicalis participující na biodegradaci fenolu. Biodegradace VI, Seč, 2003, s. 9-13.

[10] SMITH, J.R. et al. Bioremediation of PCB and PAH - containing sludge, sediments in land treatment units achieve risk - based endpoints. Hazard. Ind. Wastes, 28th, 1996, p. 309-318.

[11] HOLDEN, P.A. and FIRESTONE, M.K. Soil microorganisms in soil clean up. How can we improve out understanding? Environ. Qual. 26, 1997, p. 32-40

[12] HARMS, H. and BOSMAN, T.N.P. Mass transfer limitation of microbial growth and polutant degradation. Microbiol. 18, 1997, p. 97-105.

[13] MASÁK, J. a kol. Speciální mikrobní technologie. Skripta. Praha: VŠCHT, 1992

[14] FEČKO, P. a kol. Environmentální biotechnologie. Ostrava: VŠB - Technická univerzita Ostrava, 2004. 180 s. ISBN 80-248-0700-9.

\section{Autoři}

Ing. Tomáš Sezima, Ph.D.1

凶tomas.sezima@vuv.cz

ORCID: 0000-0003-0258-6511

Ing. Eugen Sikora, Ph.D.

凶eugen.sikora@vuv.cz

ORCID: 0000-0002-4574-2118

doc. Dr. Ing. Radmila Kučerová ${ }^{2}$

冈radmila.kucerova@vsb.cz

ORCID: 0000-0001-7242-5743

'Výzkumný ústav vodohospodářský T. G. Masaryka, v. v. i.

${ }^{2}$ Hornicko-geologická fakulta, VŠB - Technická univerzita Ostrava

Příspěvek prošel lektorským řízením.
POSSIBILITIES OF COMBINED WAYS OF

TREATMENT FOR SELECTED WASTE TYPES USING AN EXPERIMENTAL EQUIPMENT FOR PHYSICAL WASTE TREATMENT WITH THE INTENTION OF THEIR FURTHER USE

\section{SEZIMA, T.'; SIKORA, E. ; KUCEROVA, R. ${ }^{2}$}

${ }^{1}$ TGM Water Research Institute, p.r.i.

${ }^{2}$ Faculty of Mining and Geology, VSB - Technical University of Ostrava

Keywords: environment - waste - waste treatment physical waste treatment - reducing hazardous properties - biotechnology - biodegradation

This article presents possibilities of a unique device for industrial waste treatment using a patented process, and outlines possible future directions. This device, using different physical processes, individually or in synergy, e.g. combined effects of ultrasonic waves, focused microwave field, arc discharges, electrostatic field and the exposure to ultra-violet radiation, is intended to degrade dangerous substances in waste, reducing its hazardous properties for the environment and to prepare the waste for future applications (material or energy), i.e. separately or in combination with other technology processes, such as biotechnology.

DOI: $10.46555 /$ VTEI.2020.09.001 